\title{
Farmer Children's Willingness for Dairy Farming Succession in Banyumas Regency
}

\author{
Krismiwati Muatip and Moch Sugiarto \\ Faculty of Animal Science, Jenderal Soedirman University, Purwokerto 53123, Indonesia \\ Corresponding author email: krismiwati@gmail.com
}

\begin{abstract}
The objectives of this research were to 1) observe the age, education, farm parents' cattle ownership, parents' income, children's perception and willingness for farming succession, and 2) investigate the relationship between age, education, farm parents' cattle ownership, parents' income, children's perception of and willingness for farming succession. Purposive sampling was used to determine the regional sample in three districts in Banyumas regency with the most dairy cow population and included in the supervised area subject to "Pesat" Milk Cooperative, namely Pekuncen, Cilongok and Baturaden districts. Ninety respondents from 10-30 years old were determined. Result showed that farmers' children had better education than the parents with average age of 21,67 years old. Average cattle ownership was 1-15 heads per household with Rp 564,167 - Rp 4,523,333 monthly income. Farmers' children shaped positive perception on dairy farming and had willingness for farming succession. Age was positively correlated with farming perception and willingness of the farmers' children, while education was negatively correlated.
\end{abstract}

Key words: farmer children's perception, willingness to farm, education, age, income

Abstrak. Penelitian bertujuan: 1) Mengkaji umur, pendidikan, jumlah ternak sapi perah milik orangtua, pendapatan orangtua, persepsi anak dan kemauan anak untuk melanjutkan usaha sapi perah orangtuanya dan 2) Mengetahui hubungan antara umur, pendidikan, jumlah ternak sapi perah milik orangtua, pendapatan orangtua dengan persepsi anak dan kemauan anak untuk melanjutkan usaha sapi perah orangtuanya. Metode penetapan sampel wilayah yang digunakan yaitu purposive sampling, dengan memilih 3 kecamatan di Kabupaten Banyumas yang memiliki populasi peternak sapi perah terbanyak dan merupakan daerah binaan Koperasi susu "Pesat" yaitu Kecamatan Pekuncen, Cilongok, dan Baturraden. Penetapan sampel responden usia 10-30 tahun) sebanyak 90 orang. Hasil penelitian menunjukkan bahwa anak peternak memiliki pendidikan yang lebih baik dari orangtuanya dan berumur rata-rata 21,67 tahun. Kepemilikan ternak berkisar antara 1 hingga 15 ekor per rumah tangga peternak, sedangkan pendapatan yang diperoleh sebesar Rp $564.167-\mathrm{Rp}$ 4.523.333/bulan. Anak peternak memiliki persepsi baik terhadap usaha sapi perah juga memiliki kemauan untuk melanjutkan usaha orangtuanya. Umur berkorelasi positif dengan persepsi dan kemauan beternak anak peternak tetapi pendidikan memiliki korelasi negatif terhadap kemauan anak peternak untuk melanjutkan usaha orangtuanya.

Kata kunci: Persepsi anak peternak, kemauan beternak, pendidikan, umur, pendapatan

\section{Introduction}

Dairy farming in Banyumas has long been established by the society precisely in 1987 through funding by European Economic Community (EEC). To date, however, dairy farming is relatively stagnant. Muatip and Aunurohman (2004) reported that dairy cow ownership in 2003 in Banyumas was 3-5 head/household. In 2015, the number remained within the range. It indicated that dairy farming has not shown a sustainable farming development system, whereas milk is one aspect in farming with strategic role to fulfill food demand and increase national revenue (Simamora, 2015).

In fact, when diligently managed, dairy farming should be able to improve farmers' welfare because it produces milk every day to support farmers' household. Milk as dairy farming product is an important food product for health because of the nutrient content; therefore, dairy farming serves as the most important fundamental to establish food security. Besides milk, manure and urine are 
dairy farming by-products with economic value to fertilize plants or to compose renewable energy to cut down farmers'household expense. Heifer are also dairy farming product to increase cattle ownership.

Regeneration is very essential for a sustainable dairy farming. Regeneration means how dairy cow business run by the parents can be preserved or developed by the children. Whether or not farmers' children want to continue the dairy cow business has been noted since the age of 10 . At this stage, children start to understand and comprehend life events, including the character that sparks perception of a profession. Environment and circumstances around the farmers' children are visible and sensible and therefore affect perception and decision to determine their future. A good perception of dairy farmingis expected to encourage farmers' children to follow their path. Regeneration of dairy farmingis desired to make it more developed and sustainable to support milk self-sufficiency Indonesia.

Purposes of this research were 1) to observe the age, education, parents' cattle ownership, parents' income, children's perception and willingness of farming succession. 2) to investigate the relationship between ages, education, parents' cattle ownership, parents' income, children's perception and willingness of farming succession.

\section{Materials and Methods}

\section{Sampling and variables}

Purposive sampling was used to determine the regional sample for three districts with the highest dairy cow population. According to Sugiyono (2013), purposive sampling was setting the sample based on certain consideration. Sample items were specifically chosen in line with research purpose to obtain the more representative data. In this research,
Pekuncen, Cilongok and Sumbang districts were the monitored area of "Pesat" Milk Cooperative. Sample respondents were $50 \%$ of the total 209 members of the cooperative (Annual Meeting Report, 2015), thus 105 farmers. Then farmers children were subject to census (10-30 years old), making up 90 respondents.

The observed variables were the perception of farmers' children of dairy farming $\left(Y_{1}\right)$, farmers' children willingness to farming $\left(Y_{2}\right)$, age of farmers' children umur anak peternak $\left(X_{1}\right)$, education of farmers' children $\left(X_{2}\right)$,parents' income $\left(X_{3}\right)$, and parents' cattle ownership $\left(X_{4}\right)$.

\section{Operational definitions}

1. Age is the age of farmers' children in year unit, round off to the nearest year.

2. Education is the length of formal education taken by farmers' children in year unit.

3. Income is farmers' revenue from dairy farm (milk and waste/manure sell, and cattle added value) in rupiah unit within a year.

4. Dairy cow ownership is the number of cattle owned by farmers in head unit.

5. Perception is the view of farmers' children on the sustainability of dairy farm measured from the children's point of view, the benefit for society and economic value of dairy farm. Perception was measured in 1-4 likert scale.

6. Willingness to farm is the desire of farmers' children for farming succession.

\section{Data analysis}

Descriptive analysis was performed to provide information on age, education, farm parents' cattle ownership, parents' income, children's perception of and willingness for farming succession. Then, Spearman's rank correlation was used to analyze the relationship between on age, education, farm parents' cattle ownership, parents' income, children's perception of and willingness for 
farming succession. Systematic Spearman's rank correlationwas as follows:

$$
r_{\mathrm{s}}=1-\frac{6 \sum \mathrm{di}^{2}}{\mathrm{n}\left(\mathrm{n}^{2}-1\right)}
$$

Where

rs = Spearman's rank coefficient correlation

$\mathrm{n}=$ number of sample

$\mathrm{di}=$ the $\mathrm{i}$ gap

Coefficient Correlation:

$0,80-1,00$ : very strong or perfect correlation

$0,60-0,79$ : strong correlation

$0,40-0,59$ : moderate correlation

$0,20-0,39$ : low correlation

$0,00-0,19:$ no or weak correlation

\section{Results and Discussion}

Dairy farming in Banyumas has long been established by the society. Precisely in 1987, the government through Developing Baturraden Dairy Cow project funded by European Economic Community (EEC) spread 756 dairy cows. To date, the population of dairy cows keeps growing. According to Banyumas Statistics Bureau in 2015, 1567 dairy cows were spread in 8 districts in Banyumas. Dairy farming was strengthened by the Livestock Breeding Center for Excellence and Forage (BPTU-HMT) in Baturraden.

Observed from the initial ownership, cattle ownership was from legacy (40.95\%), selfpurchase (21.91\%),government support with credit system (through cooperatives) (28.57\%) and entrusted cattle (8.57\%). Based on the data, it was obvious that the majority of dairy cow farmers in Banyumas succeeded parents' farm (legacy). In line with Sentosa (2013), dairy farming knowledge was obtained from farm parents.

All dairy farmers in Banyumas sold milk product to "Pesat" Milk Cooperative. Although many farmers were not the cooperative members, they entrusted their milk product to other farmer member to sell in the cooperative.
Based on the Annual Report of "Pesat" Cooperative, milk production of the members was 5,097 liter/day.

Farmer children's age was 12 to 30 years, 21.67 years on average. Age is correlated with ability to work and adoption level. Dairy cattle farming takes strong physic, high consistency and discipline. Young age has flexibility to apply innovation (Zanu et al., 2012). They are also highly adaptable and tolerant to innovation development.

Research on dairy farmers in Ireland reported that farmer's age significantly affected motivation to develop dairy farming (McDonald et al., 2013). Young farmers had less asset or savings than the aged farmers, but showed a proficient ability of business planning. Therefore, young farmers need capital support to develop their farm.

Farmer's children had adequate education although some were only primary school graduates. The average education was 11.08 years or equal to the second year in high school. Farmer children's education was relatively better than the parents'. Education is a longterm investment for life. Education gives someone broad insight and good analytical ability prior to decision-making. McDonald et al. (2013) reported that dairy farmers in Ireland that followed farming development program had certificate of at least 180-hour dairy farming course. Education quality gives positive effect on financial performance of dairy farming. Education also significantly affects entrepreneurial behavior that enables business development (Patel et al., 2014).According to Fita et al. (2012), farmers' education, training and exposure to media are the contributing factors of farming ability. Furthermore, farming ability can serve as a reference to improve farming knowledge or skill. Parents or relatives are also the source of farming knowledge (McDonald et al, 2013).

Dairy farming in Banyumas are small-holder farming with 1 to 15 cattle ownership per 
household. The ownership was relatively stagnant year to year because dairy farming was merely a side business. Santoso et al. (2012) stated that a business belongs to side job when the venture is run in simple manner and contributes less than $30 \%$ of household income. The main job was agricultural farmer, civil servant or army and merchant. The other contributing factors to the less-developed dairy farming were limited field and capital. Dairy farming needs field to grow forage to ensure forage availability. However, farming business that is integrated with agriculture makes farmers divide the field for the two venture, and they tend to prioritize the agriculture.

Dairy farming annual income was $\mathrm{Rp}$ 6,770,000-Rp 54,280,000 from selling milk and manure and cattle price raise. Calculated monthly, the income was $\mathrm{Rp} 564,167-\mathrm{Rp}$ $4,523,333$. The price of milk was determined by the cooperative based on milk quality namely fat content and milk hygiene. The best quality was $R p$ 5,800-Rp 6,000/liter, medium quality was $R p$ 5,600-Rp 5,700/liter, and low quality was $\operatorname{Rp~5,400-Rp~5,500/liter.~}$

Farmers' income could be improved if the farmers consider cattle balance (lactating and non-lactating). To date, farmers did not pay attention to cattle balance, even eight farmers in the study did not have lactating cow. Income was obtained from the rise of cattle price. It caused detrimental effect to farmers. Improving farmers' income was also by improving feed quality. "Pesat" cooperative provided concentrate in various types and process, but most farmers chose the cheapest concentrate (RP $3,200 / \mathrm{kg}$ ). It detrimentally affected the quality and price of milk. Income from milk was merely enough to buy concentrate. As seen from income and milk selling, farmers experienced loss. Wolf et al. (2014) in the US reported that the government determined milk price that was adequate to pay feed and labor.
Integrated farming systemis a venture to improve dairy farmers' income. However, it requires farmers to own knowledge, creativity, motivation and resources. Integrated farming system can improve profit, environment conservation and farmers' community. Despite the many benefits, this system complexity can obstruct adoption (Russelle et al., 2007).

\section{Farmer children's perception on dairy farming}

Analysis result showed that most farmer children or 79 respondents had positive perception of dairy farming. Good perception might rise since the children witnessed their parents' ability to provide for family and send children to school through dairy farming although the venture was traditionally managed or only a side job. Moreover, the children felt the benefit of dairy farming. It was in line with Kunasekaran et al. (2012) that good perception rises when someone has seen and felt the benefit of an innovation (venture). The perception will get better when farmers own knowledge of entrepreneurial cow farming.

Spearman's rank analysis indicated that coefficient correlation between farmer children's age and their perception was 0.016 or positive correlation with very weak coefficient correlation. Howley et al. (2012) stated that aged farmers were relatively conservative and difficult to change standpoint.

Correlation between farmer children's education and dairy farming was -0.085 or negative correlation with very weak coefficient correlation. Education of farmers' children was relatively good but family environment was less supportive to build a good perception on dairy farming. Farmers had less time to communicate with the children and gave less guidance for their future. It might due to farmers' low level of education, limited communication skill and less knowledge on job empowerment. Many farmers did not want their children to continue farming business because dairy farming did not have fixed income and future. The children 
were encouraged to be an employee with stable monthly income.

Higher level of education should be linear to the amount of knowledge obtained by the farmers' children. Higher formal education provides the farmers' children greater job opportunity than farming business. In fact, education level affects farmers' access to information and ability to understand the technical aspects of innovation that help accelerate adopting innovation (Zanu et al., 2012).

Farm parents' cattle ownership was positively correlated $(0.054)$ with the children's perception of dairy farming. The more cattle owned, the more positive the perception. However, the very weak correlation indicated that parents' cattle ownership was not correlated to children's perception on dairy farming; instead, there was tendency to positive correlation. It was due to relatively equal cattle ownership among farmers. Farmers were reluctant to add more cattle due to some reasons: 1) farmers had limited forage area, 2) farmers had limited workers or time because dairy farming was integrated with agriculture and 3) farmers had limited resources that discouraged them to adopt innovation and to build collaboration with other parties.

The more cattle ownership, the more positive children's perception on dairy farming. Positive perception of a profession affects the interest to toil in the profession. Perception is related to the subject (individual) interest on the observed object (Abdullah, 2015).

Parents' income was positively correlated with farmer children's perception with 0,279 coefficient correlation, indicated a weak correlation but very significant relationship. Parents' income from dairy farming has shaped positive perception to children of dairy farming.

\section{Willingness to farm of dairy farmers' children}

All research respondents were male children. Total of 82 children (91.11\%) were willing for dairy farming succession, while 8 children (8.89\%) were doubtful. Farmer children's willingness to continue dairy farming was likely due to interest in the business and perception that it has a promising potential. As reported by Kiama (2016), women are more careful to make decision. Children's interest to dairy farming needs support by a good communication between them and parents. Children should be involved in breeding because it served as non-formal education process.

Correlation between farmer children's age and willingness for succession was a positive 0.027. Small correlation value is disregarded, thereby age is not correlated with the willingness to farm in farmers' children, but it tends to have positive correlation. A good perception of dairy farming makes children willing to continue their parents' business, although they did not instruct the children to follow their path. The older the children, the more willing for succession. It was probably because the majority of dairy cows were obtained by legacy. A credence in Banyumas was that legacy is not for sale.

Education of farmer children negatively correlated $(-0,007)$ with willingness to farm. The very low correlation indicated that education level was not correlated but tended to be negatively correlated. Higher education enables someone to make predictions on a business. Copeland and Dharmasena (2016) stated that milk consumption in America has declined for the last 25 years, might due to the increasing awareness of health. Alternative drink (soya milk, almond milk) is generally considered a more healthy choice because of less calorie and minus growth hormone content as in dairy milk. Higher education enables someone to make a more objective assessment because they have more 
information from a higher ability to access information.

Farm parents' cattle ownership was positively correlated $(0.044)$ with the children's willingness for farming succession. Small correlation value showed that parents' cattle ownership was not correlated to children's willingness to farm but it tended to have positive value. If the more cattle owned was balanced with the correct composition of cow's age, it could sustain farmers' income.

Farmers' income was positively correlated (0.149) with children's willingness for farming succession. The higher the income, the more expectation to improve farmers welfare. A study by Wahyudi (2014) of "SAE" cooperative members in Malang found that cow ownership encouraged members' productivity. Besides, the more cows owned, the higher milk production. The increasing output was linear to farmers' income and therefore stimulated the farmer children to continue parents' farming.

Perception and willingness for farming succession had moderate coefficient correlation (0.586). Daniar et al. (2014) stated that the youth perception affects their interest on certain object. According to Arifianto and Sukanti (2014) willingness can derive from themselves and make them do efforts to achieve the goal. Willingness or desire from themselves is usually influenced by some factors, one of which is upbringing pattern. Family upbringing can affect children's interest to be dairy farmer. Previous studies reported that a mother is the dominant nurture, so mother holds an important role to bring up the children to be a dairy farmer. Willingness to farm in this study was in high category because not all mother who brought up the children also helped their husband to take care of cows in the farm. Accordingly, knowledge and experience in dairy farming was limited, so only a little information on dairy farming was passed on to the children.

\section{Conclusions}

Children of dairy cow farmers are in productive age with considerably high education. The age of farmers' children positively correlated with children's perception of dairy farm and willingness to continue parents' business, while children's education negatively correlated with the perception of dairy farm and willingness to continue parents' business. Parents' income and cattle ownership positively correlated with children's perception of dairy farm and the willingness to continue parents' business, moreover the better children's perception the more willingness to continue dairy cow business.

\section{References}

Abdullah A. 2015. Farmers' perception on the work of extension agent in improving technology of hay processing and beef cattle waste. Jurnal IImu and Teknologi Peternakan Tropis 1(1)

Koperasi Pesat. 2015. Report of Annual Member Meeting 2015. Purwokerto

Arifianto F and S Sukanti. 2014. Effect of selfmotivation and perception on public accountant profession on the interest to be public accountant in the students of Accounting Program, Economics Faculty, Yogyakarta State University. Jurnal Nominal 3(2).

National Statistics Bureau. 2015. Banyumas In Numbers. Purwokerto.

Copeland A and S Dharmasena. 2016. Impact of increasing demand for dairy alternative beverages on dairy farmer welfare in the United States. Southern Agricultural Economics Association's 2016 Annual Meeting, San Antonio, Texas.

Daniar GR , BA Nugroho and E Nugroho. 2014. Perception and interest of young people in Madura cattle agribusiness (Study in Waru Districts, Pamekasan Region). Jurnal IImu-IImu Peternakan 24(3):69-78.

Fita L, MM Trivedi and B Tassew. 2012. Adoption of improved dairy husbandry practices and its relationship with the socio-economic characteristics of dairy farmers in Ada'a Distric of Oromia State, Ethiopia. Jurnal Agricultural Extension and Rural Development 4(14):392-395.

Howley P, CO Donoghue, K Heanue. 2012 Factor affecting farmers' adoption of agricultural 
innovation: A panel data analysis of the use of artificial insemination among dairy farmers in Ireland. Jurnal of Agricultural Science. 4(6):171179.

Kiama TN, Lindahl JF, Sirma AJ, Senerwa DM, Waithanji EM, Ochungo PA, Poole EJ, Kang'ethe EK and Grace D. 2016. Kenya dairy farmer perception of moulds and mycotoxins and implications for exposure to aflatoxins: a gendered analysis. African Journal of Food, Agriculture, Nutrition and Development. 16(3):11106-11125.

Kunasekaran P, S Ramachandran, Z Samdin, KW Awang. 2012. Factors affecting farmers' agro tourism involvement in Cameron Highlands, Pahang. OIDA International Journal of Sustainable Development. 4(1):83-90.

McDonald R, Pierce K, Fealy R and Horan B. 2013. Characteristics, intentions and expectations of new entrant dairy farmers entering the Irish dairy industry through the new entrant scheme. International Journal of Agricultural Management. 2(4):189-198.

Muatip K, M Sugiarto and I Haryoko. 2015. Study on cow milk marketing in Central Java to support milk sustainability. Kajian Pemasaran Susu Sapi Perah di Jawa Tengah untuk Mendukung Swasembada Susu. In: Proceeding Unsoed. Purwokerto.

Patel P, Patel MM, Badodia SK and Sharma P. 2014. Entrepreneurial behaviour of dairy farmers.
Indian Research Journal of Extension Education 14(2):46-49.

Russelle MP, Entz MH and Franzluebbers AJ. 2007. Reconsidering integrated crop-livestock systems in North America. Agronomy Journal 99(2):325334.

Santoso K, S Warsito, and A Andoko. 2012. Feedlot business. Agromedia Pustaka. Jakarta.

Santosa SI. 2013. Analysis of potential development of dairy cattle business under agribusiness paradigm in Musuk district Boyolali Region. Jurnal Buletin Peternakan. 37(2):125-135.

Sugiyono. 2013. Non-parametric Statistics for Research.Alfabeta. Bandung.

Simamora T, AM Fuah, A Atabany and Burhanuddin. 2015. Evaluation on technical aspect of smallholder dairy farming in Karo Region North Sumatra. Jurnal IImu Produksi and Teknologi Hasil Peternakan. ISSN 2303-2227. 03(1):52-58.

Wahyudi A. 2014. Analysis of Contributing factors to the income of Dairy Cattle cooperative members (A case study in SAE Cooperative member Pujon District, Malang Region). Jurnal Ilmiah. Universitas Brawijaya. Malang.

Wolf CA and Widmar NJO. 2014. Adoption of milk and feed forward pricing methods by dairy farmers. Journal of Agricultural and Applied Economics 46(4):527.

Zanu HK, Antwiwaa A And Agyemang CT. 2012. Factors influencing technology adoption among pig farmers in Ashanti Region of Ghana. Jurnal of Agricultural Technology 8(1):81-92. 